\title{
Las pasiones de Sócrates
}

\author{
DAVID MORALES TRONCOSO \\ Universidad Diego Portales (Chile) \\ david.morales@udp.cl
}

\begin{abstract}
Resumen
Este artículo sobre antropología, ética e historia de la filosofía, propone de modo sistemático relacionar aspectos fundamentales de la filosofía del Sócrates Platónico, a saber, su propuesta ética y la experiencia del eros. Para tal efecto se toma como punto inicial un texto del Gorgias platónico, donde Sócrates admite dos grandes pasiones: la filosofía y su amor por Alcibíades. La indagación conducirá, primeramente, a revisar la piedad cívica de Sócrates, entendida como un racionalismo religioso, y que toma la forma de una práctica especial de justicia. En segundo lugar se mostrará que su afán por emular a la justicia divina contrasta con las impiedades de su amigo Alcibíades, exponiendo resultados paradojales en relación al magisterio de Sócrates, lo que genera problemas sobre la efectividad de sus ideas teológicas y su filosofía ética.
\end{abstract}

Palabras clave: Sócrates, Alcibíades, piedad y justicia, eros y filosofía.

\section{The Passions of Socrates}

\begin{abstract}
This article on anthropology, ethics and the history of philosophy, proposes from various disciplines the relation between fundamental aspects of the philosopby of the Platonic Socrates, such as the ethics and the erotic experience. Thus it takes, as a starting point, a text from the platonic Gorgias, where Socrates admits his two great passions, philosophy and his love to Alcibiades. The inquire proceeds, in the first place, to consider the civic piety of Socrates, namely his theological rationalism, that takes the form of a special practice of justice. In second place, it will show that, ironically, his effort to imitate the divine justice will contrast with the impiety of his friend Alcibiades, having paradoxical results in relation to the teachings of Socrates. This situation will generate new problems about the effectiveness of his theological ideas, ethical proposals and philosophical views.
\end{abstract}

Key words: Socrates, Alcibiades, piety and justice, eros and philosophy.

Doctor en Filosofía por la Pontificia Universidad Católica de Chile. Profesor de Antropología filosófica y Ética en la Universidad Diego Portales y en la Pontificia Universidad Católica de Chile. También profesor de Filosofía y Ética en la Escuela Militar de Chile. Su área de investigación es principalmente la filosofía antigua y tiene a su haber cerca de veinte publicaciones en revistas especializadas de humanidades en Chile, Sudamérica y Europa. Además, fue Secretario de redacción de la revista Diadokhe.

Este trabajo forma parte del Proyecto FONDECYT N ${ }^{\circ}$ 1070618, titulado Eros y Filosofía en la Filosofía de Sócrates (2007-2010). 


\section{Prolegómenos}

El personaje del Sócrates Platónico de los diálogos Tempranos (SPT en adelante) ${ }^{1}$, se caracteriza por la movilidad de su método dialógico y por su actitud irónica, cuyos rendimientos inquisitivos redundan casi siempre en diversas conclusiones paradójicas. Así resultan ser las formas propias de su comportamiento discursivo: un quehacer filosófico de naturaleza dialogante, donde aparece un tanto serio como también lúdico. $\mathrm{El}$ autor a veces lo presenta como un irónico sabio, ignorante de su saber, y con una capacidad única para escaparse de todas las determinaciones posibles. De allí la naturaleza paradojal del personaje que figura en los diálogos de la primera época de Platón.

No obstante la impostura del personaje, reconocible también en su característica declaración de ignorancia en temas de ética y filosofía, es posible recabar ciertas certidumbres fundamentales en el personaje del SPT. Puesto que al reverso de su agnoia metodológica, encontramos también un cierto saber positivo que, a nuestro juicio, servirá para penetrar en los secretos del socratismo y de paso será clave para resolver algunas de sus paradojas fundamentales.

Este saber positivo contiene un cierto conocimiento sobre «las cosas del amon» (ta erotika $\hat{\text { ) }}$, como un saber eminentemente discursivo, y que el personaje platónico confiesa detentar en contadas ocasiones ${ }^{2}$. Junto con esta declaración de saber substantivo sobre los asuntos amorosos, también podemos advertir una marcada preocupación por las vidas de sus amigos y compañeros de plática, como un rasgo importante de su personalidad compleja y atípica.

Para ilustrar el alcance de estas observaciones preliminares, rescataré un conocido pasaje del Gorgias platónico. Aquí se narra el encuentro inicial de Sócrates con el sofista Calicles, que determinará el giro final de este agónico diálogo socrático de Platón. En el contexto previo se ha

\footnotetext{
1 Para efectos de construir nuestra hipótesis de interpretación hay que tener presente que la obra de Platón se puede dividir en al menos tres momentos teóricos: los diálogos de la primera época, los de su mediana edad o madurez, y los tardíos o del período crítico. Nuestro interés se centra en los diálogos de la primera época y de transición. De allí que utilicemos la sigla SPT = Sócrates Platónico Temprano, para enfatizar los alcances y límites de nuestra indagación hermenéutica. Para un tratamiento exhaustivo de esta división remito al libro de G. VLASTOS: Socrates, Ironist and Moral Philosopher. Cambridge University Press, Cambridge 1994.

2 Cfr. Banquete, 177d5; Lisis, 204c. Para las traducciones de Platón se utilizo como referencia las ediciones de Gredos, Madrid 1992ss. Eutifrón traducido por J. Calonge Ruiz.
} 
producido ya la refutación a Gorgias y a Polo, y ahora el diálogo se dirigirá hacia Calicles, quien entra en la escena como interlocutor:

Calicles: Dime Sócrates, hemos de suponer que hablas en serio o que estás bromeando (paixein)? Porque si hablas en serio y lo que dices resulta verdadero, ¿no sería la vida humana volteada entre nosotros y, al parecer, hacemos todo lo contrario de lo que se debe?

Sócrates: Calicles, si a los hombres no les sucediera lo mismo - a unos esto y a otros aquello- sino si alguno de nosotros le pasara algo distinto de los demás, no sería fácil indicar a otro el estado de uno mismo. Digo esto porque he notado que ahora, yo como tú estamos en la misma situación: cada uno ama a dos (erônte duo onte duoin ekateros): yo a Alcibíades, hijo de Clinias, y a la filosofía; y tú al Demos de los atenienses y al hijo de Pirilampo. Me percato de que cada vez - por hábil que seas- eres incapaz de contradecir a tus favoritos (ta paidikâ) en cuanto a lo que dicen y lo que dicen que es algo ${ }^{3}$.

A continuación desarrollaré una interpretación de esta resonante declaración concerniente al foco de las pasiones del Sócrates platónico, de manera de situar una posible relación entre las dos grandes pasiones declaradas por Sócrates: la filosofía, entendida ésta como un quehacer de reflexión que lo compromete existencialmente, y por otro lado, su inclinación personal por Alcibíades, cuya relación se hizo célebre en la abundante historiografía y que suele surgir como una tensión sin resolver en la figura del sabio Sócrates, un hombre perfecto para sus apologetas, y que en el plano de los afectos también podría dar lecciones de virtud, tanto en la teoría como en su experiencia personal del eros.

Para efectos de un desarrollo sobre las pasiones socráticas, a continuación expondré una interpretación esencial del quehacer filosófico del SPT, centrándome para tal efecto en los diálogos apologéticos del Platón Temprano ${ }^{4}$. De esta manera podré reunir los elementos de juicio que serán fundamentales para construir una representación coherente de su filosofía, para que se establezca luego una

Gorgias, 481d.

Según la tradición alejandrina, la primera tetralogía de obras de Platón contiene los cuatro diálogos que refieren el contexto del juicio que condenó a Sócrates, que suponemos tienen valor histórico relevante para nuestro actual propósito. Este ordenamiento se atribuye a Claudio Tiberio Trasilo, astrólogo de Alejandría muerto el año 36 d.C., y que en vida se había ganado la confianza de Tiberio. Más tarde, durante la época medieval, este modo de agrupamiento se mantuvo en las copias de los manuscritos hasta nuestros días, tal como figura en las ediciones oxonienses del siglo XX. Para más detalles Cfr. O. VelásQueZ: "La transmisión del texto de Platón: vicisitudes de una historia”, Onomázein, 15/1 (2007), 157-173. 
posible relación entre la pasión por este saber y la señalada amistad con quien fuera por mucho tiempo su amigo favorito (ta paidiká, según la expresión de la época).

\section{La pasión por la justicia en SPT}

La búsqueda de la justicia divina es el tema central del quehacer del socratismo clásico, y es en el diálogo Eutifrón, sobre la piedad (peri to hosion), donde este motivo surge inicialmente, tanto como soporte dramático del diálogo, como también en la respuesta decisiva a la comprensión sobre lo que debe ser la piedad verdadera, a saber, una parte de la justicia relacionada con lo divino.

Como efecto inmediato de estas premisas socráticas, pretendo demostrar en lo que sigue que es posible una interpretación positiva de este diálogo, que es dramáticamente aporético, y cuyas respuestas completas al enigma del saber del SPT, deben complementarse con los otros diálogos apologéticos ${ }^{5}$ para tener una buena comprensión sinóptica de su piedad y su filosofía ética.

De aquí que, en la estructura dramática inicial del texto, encontramos, después de establecerse los casos judiciales de Sócrates y de Eutifrón, que se pasa directamente a la discusión y posible definición de lo que sería piadoso y de lo que no, cuestión que se modulará dialécticamente mediante una genial técnica de contrapunto literario entre ambos personajes. Esta lectura de antinomias nos hace verosímil pensar, al personaje Eutifrón y sus creencias, como la personificación de unas ideas que son representativas de las opiniones populares de la época ( $t a$ endoxa) en materia religiosa, de modo que por contraste, en las sucesivas definiciones y subsecuentes refutaciones, se arrojarán luces claras sobre las nociones de teología racional del SPT, de manera tal que, ambas mentalidades, la del filósofo y la del adivino, al ser opuestas en su

5 Dentro de los diálogos tempranos de Platón se puede identificar un primer subconjunto, que corresponde a aquellos en los que se tematiza el proceso judicial de Sócrates, estos son Eutifrón, Apología de Sócrates y Critón, que son los que reciben el nombre de apologéticos por tratarse de diálogos socráticos relacionados con la defensa y justificación en el proceso. En tanto, el diálogo Fedón, si bien también tiene el soporte dramático de la condena a muerte de Sócrates, corresponde más bien al grupo de los diálogos medios de Platón, cuya característica fundamental es la presencia de la teoría de las Formas como hipótesis explicativa de ciertos argumentos metafísicos. 
cosmovisión de la justicia, terminarán excluyéndose mutuamente en relación a la comprensión profunda de la naturaleza de lo divino ${ }^{6}$.

\section{Las tesis positivas del Eutifrón de Platón}

Así, entonces, y frente a las pruebas argumentales del personaje Eutifrón para justificar lo correcto de su presente acusación judicial -basadas en ciertos escrúpulos religiosos como es la creencia en la miasma, de un profesional de la mántica- queda meridianamente claro que Sócrates expresa su total rechazo frente a la tradición poética-religiosamítica. De allí que se cuestione la definición de lo piadoso como aquello que agrada a los dioses. Pues frente a este caos de fuerzas demoníacas desatadas, del pensamiento mágico y politeísta, Sócrates se propondrá investigar por el carácter propio (autó to eidos) de la piedad verdadera, de modo que le sirva de paradigma o medida de valor de lo pío y de lo impío?.

Con este mismo afán lógico por el silogismo perfecto, Sócrates logrará introducir un cuantificador universal en la $2^{\mathrm{a}}$ definición, de manera que Eutifrón deberá admitir que lo piadoso es «lo que a todos los dioses agrada».

A continuación, Sócrates establecerá que el agrado, o el amor que sienten los dioses por lo que es pío, no sería una condición suficiente para que un acto sea calificado como piadoso, pues el amor de los dioses sería sólo como un accidente de lo que es piadoso, cuyo aspecto fundamental descansaría en otro aspecto más esencial ${ }^{9}$. En este punto el personaje Eutifrón se confundirá con la estrategia dialógica circular del filósofo, expresando que: «no sé cómo decirte lo que pienso». En adelante dejará la iniciativa al filósofo Sócrates, que transita el episodio de confusión mediante un interludio de bromas simbólicas. En este pasaje de notable ironía, Sócrates desliza una descripción de su método, mediante la evocación del oficio experto de su antepasado Dédalo, el diseñador de esculturas animadas y del laberinto del rey Minos, entre otras obras ${ }^{10}$.

W. K. C. Guthrie sostiene que Eutifrón representa «unas tendencias fuertemente conservadoras al interior de un período de transición, lo que se muestra en la ingenua aceptación de los relatos de los poetas», que en otro lugar serán abiertamente criticados por Platón; cfr. República, 377b-387e.

Cfr. Eutifrón, 6e.

Ibíd., 9c, donde la expresión para referirse a la inclinación divina es theofilés.

Ibíd., 11a-c.

10 Existen pocas ocasiones en que el Sócrates platónico se refiere a su propio método filosófico mediante imágenes (por ejemplo, como si fuera un tábano de Atenas en 
A continuación, Sócrates concordará con Eutifrón en la tesis central del diálogo, de que todo lo que es piadoso es justo, estableciendo así una relación del todo a la parte y donde destaca que la justicia es un concepto más amplio que la piedad, pues contendría a ésta y no al revés ${ }^{11}$. Esta es la tesis fundamental del diálogo y por su tono proposicional no será refutada en ninguna parte de lo que resta de esta obra.

Sin embargo, y para describir mejor en qué consiste la parte de la justicia que es piadosa, Sócrates propondrá acordar con Eutifrón un enfoque más fenomenológico de la acción piadosa. Así resulta que la piedad podría ser una especie de cuidado (therapeia) de los dioses, definición que refutará enseguida mediante una batería de argumentos inductivos y cuestionando que el término «cuidado» tendría implicado el mejoramiento del objeto de cuidado - en este caso los dioses mismoscuestión que no se cumpliría en el caso de los divinos, que serían seres inmejorables ${ }^{12}$.

De aquí se deriva que la piedad podría ser más bien una especie de servicio a los dioses (byperethikê), teniendo presente como paradigma de relación, la que sostienen los amos con sus esclavos, y en donde la función principal del esclavo, se subentiende, es la de cumplir la voluntad de los amos que son sus dueños.

La pregunta clave del diálogo es la que surge a continuación y es la siguiente: ¿Cuál es esa bellísima obra que los dioses producen sirviéndose de nosotros como esclavos? ${ }^{13}$ A continuación me permito reinterpretar posibles respuestas a este emplazamiento. Para Eutifrón, de mentalidad mítica y politeísta, esta pregunta es incontestable, pues estas obras divinas son tan numerosas como fuerzas demónicas hubieran, cruzándose y luchando entre sí en un universo de seres divinos antropomórficos. En cambio, la respuesta de Sócrates a esta pregunta, aunque no se aclara inmediatamente, ya está en parte respondida, con la tesis que ha

\footnotetext{
Apología 31a, o como la tarea de las parteras en Teeteto, 150a). Para tal efecto, en el llamado interludio del Eutifrón (11d) se evoca con ironía a su antepasado Dédalo, inventor que poseía el arte de hacer que se desplazaran sus obras escultóricas. Esto surge en comparación con las obras hechas «de argumentos» (logoi, cfr. República, L. IX, final), que giran en círculo como las de su interlocutor (cfr. Eutifrón al final). Esta semejanza es verosímil por la acción de desplazamiento en círculos que se asemeja al método de refutación socrática y que, en este caso, concluye con la refutación de las opiniones míticas sobre la justicia divina de Eutifrón, que van diluyéndose en su confusión. De esta manera, la filiación con el artista Dédalo también se podría entender en relación con la construcción de un laberinto - de tipo conceptual- semejante al del legendario Minotauro.

11 Cfr. Eutifrón, 12a.

12 Ibíd., 13a-e.

13 Ibíd., 14b.
} 
permanecido irrefutada a lo largo del diálogo, a saber, que lo piadoso es una parte de la justicia; lo que implica de paso que todo lo pío es justo, pero no todo lo justo es lo igual a lo pío, definiéndose anteriormente y con claridad la relación decisiva entre un todo y su parte.

La respuesta completa a la intuición socrática sobre la naturaleza de la piedad, y en definitiva sobre la naturaleza divina de la justicia, se puede encontrar dispersa a lo largo de los diálogos de Platón, pero en particular en su Apología de Sócrates, Critón y Eutifrón. En estos textos su misión cívica - encomendada por el dios- de mejoramiento de sí mismo y de las almas de los ciudadanos - junto con la permanente referencia a la orientación de un daimon como señal (semeion)—, se describen como imperativos divinos y en definitiva como la base espiritual de su quehacer filosófico, considerado siempre y en todo lugar como la búsqueda apasionada de lo justo y su verdad práctica ${ }^{14}$.

En tanto, es en el Critón en donde encontramos un aspecto más propositivo y concreto de su pensamiento ético, que se expresa en la obediencia a la justicia divina, y que en el escenario del diálogo sobre el deber, toma la forma del rechazo a la ley de Talión y a toda forma de venganza o violencia como respuesta válida a una agresión. En adelante esta postura se ejemplifica y aplica como un respeto irrestricto a las leyes de la polis, que reconoce fueron acordadas libremente entre el ciudadano y la ciudad natal. Las leyes, si bien son acuerdos humanos y no son propiamente seres divinos, parecen ser inspiradas del modo más justo posible en el acuerdo cívico necesario para su generación. De tal manera que toda esta visión de los acuerdos, como paradigma de lo justo, estará en sintonía unitaria con el orden natural y los númenes divinos, según leemos en la parte final del Critón.

\section{La piedad socrática se convierte en ética}

No obstante las complejidades del asunto, lo importante aquí es establecer con firmeza, para construir nuestra hipótesis, que desde que se escribió el Eutifrón tenemos ya un testimonio ineludible de la forma fundamental de la piedad socrática, que pasa por una racionalización profunda en la comprensión de la naturaleza de los dioses. Esto consiste en que la multiplicidad de fenómenos y epifanías, se unifican bajo el criterio de la Justicia como la Forma (eidos) que servirá de paradigma de

14 En la Apología de Sócrates concibe su filosofar como servicio al dios (23c, 38c) en beneficio de los atenienses (30a). En tanto, G. Vlastos (1994) también ha visto la conexión entre este servicio al dios con la concepción de piedad que aparece en el Eutifrón. 
valor para los actos del hombre que, como Sócrates, está avanzando, mediante la práctica de las virtudes, en el largo proceso de divinización que señala la vida del sabio.

Por otra parte, varios autores han reparado en que el fundamento último de la filosofía de Sócrates se encuentra en un núcleo místico y religioso, y en donde conviven en una pacífica cohabitación la racionalidad ética y la experiencia mística o religiosa ${ }^{15}$. De tal suerte la piedad de Sócrates paradójicamente también sería la forma de su impiedad. Puesto que la base fundamental de su piedad proviene y se apoya en la premisa mayor de que todo lo divino es justo, se subordinará así el poder parcial de todos los dioses que figuran en los relatos de los poetas, a un orden superior de justicia, que desde una dimensión superior los sostiene y regula. De tal suerte su teodicea racionalista resulta estar en franca oposición con las concepciones míticas de la tradición, que suponemos representada y personificada en el adivino Eutifrón.

Puesto que la relación con lo divino, para este Sócrates (SPT), está contenido en lo justo, su forma eidética iluminará siempre el quehacer del hombre piadoso = justo; transformándolo, mediante el ejercicio de la revisión y el autoexamen, en la disposición virtuosa correspondiente, pues lo anterior se logra en virtud de la contemplación sostenida del paradigma superior de la justicia y la atención permanente a sus señales divinas.

De allí se entenderá que, para el verdaderamente piadoso, lo justo es todo lo que recibe como gracia de lo alto - como una porción de la moira o daimon que toca en suerte- incluyendo por cierto el misterio indescifrable de ciertos males, que le pueden acontecer al hombre justo, $y$ que para este Sócrates heroico no serían males en verdad, sino bienes reales, aún cuando su saldo inmediato sea negativo en apariencia ${ }^{16}$.

15 Cfr. T. Calvo: "Sócrates", en Enciclopedia Iberoamericana de Filosofía 14: Historia de la filosofía antigua. Trotta, Madrid 1997, 118. Allí se establece que «Sócrates parece profundamente convencido de que las exigencias de la religión y de la razón son perfectamente compatibles».

16 Desde la Apología de Sócrates su noción de filosofía se comprende como una misión, y puesto que es un mandato divino, Sócrates está dispuesto a cumplirlo a cualquier precio, incluido el de su propia vida (cfr. 28e, 29.c.d). De tal manera, la ética de Sócrates contiene claramente la impronta del heroísmo, debido a que es un individuo que defiende un valor que considera por encima de su propia vida. Para iluminar de otra forma la pasión de la ética socrática, existe un texto platónico tardío sobre el origen del término héroe: «En lo que toca al nombre, está muy poco desviado del nombre del amor (érôs) del cual nacieron los héroes (hêrôes). Esto es lo que define a los héroes, o bien el que eran sabios y hábiles oradores y dialécticos, capaces de preguntar (erôtân)»; Cratilo, 398d5. En efecto el héroe es el que ama apasionadamente algo distinto de sí mismo. En 


\section{Una alegoría paralela desde el estoicismo}

Por otra parte, una hermenéutica tentativa para comprender el núcleo de la piedad socrática, se podría construir en analogía con el símbolo de una trinidad de tradición pagana y de matriz estoica ${ }^{17}$. De tal suerte podemos reinterpretar con este símil la triple dimensión de la experiencia socrática de justicia: la que se da entre el hombre y lo divino, entre el hombre piadoso y el hombre citadino y, por último, con la figura materna de polis. Esta alegoría funcionaría como un esquema puramente instrumental para tratar de comprender mejor, mediante símiles, cómo operaría la piedad $-\mathrm{O}$, si se quiere, la religión- del SPT. De tal suerte, encontramos esta interesante figura para comprender el asunto, a la vez unitario y múltiple, en la figura simbólica de matiz estoico de las tres gracias, para tal efecto cito a Séneca:

Puesto que lo esencial en la gracia es el acto de dación, en ella se simbolizan los tres momentos de ese acto cuando es perfecto, el triple ritmo de la generosidad: gracia en el dar, en el recibir y en el devolver. Pues: ¿Qué significa aquel coro que forman, volviendo a replegarse en sí mismas, trabadas de las manos? Que el orden del beneficio, pasando de mano en mano, revierte de todas maneras al bienhechor, y que se pierde la belleza del cerco que hacen las tres si se rompe en algún momento; en cambio la conserva toda si se mantiene compacta y guarda el ritmo debido ${ }^{18}$.

el caso del Sócrates de los diálogos apologéticos, la Polis es lo más querido y es el objeto de su eros, pues siendo un gran amante de su patria (como sujeto, en sentido activo), fue capaz de dar su vida por ella y su sacrificio personal, en lo sucesivo, lo convirtió también en un héroe moral de culto y de veneración apasionada por sus discípulos y las futuras generaciones de filósofos, alcanzando así la inmortalidad terrena y quién sabe si también la vida eterna, que «es algo oculto para todos, excepto para el dios»; cfr. Apología, 42a.

17 Ya está dicho que la diferencia fundamental entre el pensamiento mítico de la época arcaica y el socratismo teológico de Sócrates estaría en que la noción de justicia se identifica con el contenido superior de lo divino, como una especie de gracia para dar a los hombres. De tal forma, el objeto de contemplación pura es equivalente a la forma trascendente de la justicia, como paradigma superior, que inspira la práctica de su misión filosófica y su acción dialógica para mejorar a los otros mediante su propia justificación. Esta relación de divinización, o transmisión de los dones divinos de la justicia se nos representa, de modo más verosímil, en el Critón, como el compromiso moral con lo divino y con las leyes de la ciudad, que fueron acordadas libremente y que tienen por eso un poder vinculante y re-ligante.

18 SÉneCA: De Benefici, I, 3. Extractado del libro de F. J. FOLCH: Sobre símbolos. Editorial Universitaria, Santiago de Chile 2000, 73-74. Las citas siguientes corresponden a la misma edición. 
De modo que la imagen danzante de las tres gracias busca enseñar a los hombres a dar de buen grado, recibir de buen grado y proponerles la gran emulación de no solamente igualar, sino aun vencer en obra y en deseo a aquellos a quienes deban agradecimiento, en la honrosa competencia de vencer los beneficios con los beneficios. De tal suerte la gracia (xaris) sería como «el reflejo en lo individual inferior de la belleza universal e inmutable», ya que la evocación de estas figuras simbólicas sirve también para tender puentes de comprensión hacia el complejo concepto de justicia que está detrás de SPT, de suerte que quizás montados sobre estos símbolos alegóricos alcancemos a intuir mejor la experiencia de la filosofía que señala Sócrates.

Volviendo a una línea de especulación de la teología socrática, como un esquema instrumental de análisis, me atrevo a señalar que el demonio socrático no emite una radiación de caridad gratuita, pero que invita en cambio a descubrir una singular experiencia de lo justo, en al menos tres niveles:

1) En ser justo para contemplar el valor trascendente de lo divino, traducible en la actitud religiosa correcta para aceptar los dones $=$ bienes, de los dioses.

2) Ser justo en la relación con el otro, en la medida en que no se debe hacer daño voluntariamente y así alimentar el compromiso ético con la vida virtuosa.

3) Por último, ser justo para mantener en el tiempo los acuerdos que se han celebrado con un espíritu libre de coerción. Este es el caso del respeto a las leyes de la ciudad, que también representan fuerzas religantes de la polis, y que en el coro trágico del Critón, surgen con la forma espectral de los espíritus de los $\operatorname{antepasados}^{19}$.

Así es como se puede a grandes rasgos describir mediante algunos esquemas instrumentales la filosofía del SPT, a saber, una pasión por la justicia que se despliega en los paradigmas de la pasión por conocer, la pasión por su misión divina y, por último, en la pasión por el deber ser en una doble dimensión de una ética heroica y legalista que se apoya en la fidelidad de los acuerdos cívicos.

19 En un posible esquema tentativo, la piedad socrática se podría resumir como una devoción a: «La Justicia como Idea», como el paradigma intuido por el hombre piadoso; La «Justicia como virtud», al imitar la orientación hacia la bondad de la naturaleza de lo divino); y «Justicia cívica», en la acción sostenida de respetar los acuerdos, en particular de las normas sancionadas positivamente y que toman la forma del compromiso con las leyes. 
Una vez establecida nuestra lectura fundamental de la filosofía ética socrática, conviene ahora revisar brevemente el aspecto más mundano de las pasiones de Sócrates, mediante el escrutinio biográfico de su amigo más reconocido y que, irónicamente, arrojará un resultado paradójico.

\section{La pasión por Alcibíades}

Como se sabe, Alcibíades (450-404 a.C.) fue militar de profesión y un famoso político ateniense ${ }^{20}$. Huérfano de padre a los tres años, pasó su juventud en casa de su tío y tutor Pericles (495-429 a.C.). En tanto, la relación con Sócrates habría tenido lugar desde aproximadamente el 430. Después, desde 420 a 406, en los años de la guerra del Peloponeso se convirtió en el motor de la política de Atenas, generando entre otros eventos la coalición con Argos, la expedición a Sicilia y la revolución de los 400. Exiliado de Atenas también aconsejó militarmente a Esparta primero y a Persia después, y aunque logró volver a Atenas con honores en 407, fue desterrado de nuevo y murió asesinado por sicarios en Frigia en el 404, a los 46 años de edad.

\section{Algunos aspectos psicohistóricos}

Alcibíades dejó huella imborrable en historiadores, poetas y filósofos de la ilustración ateniense. Su personalidad brillaba por donde estuviera, pues de todas las cualidades que más se apreciaban, este noble ateniense del clan de los Alcmeónidas por línea paterna, militar de profesión y buen retórico, prácticamente las tenía todas. Sin embargo, esta multiplicidad de dones unida a una ambición desmedida y a un carácter exaltado, jugaron a la larga en su contra, en una vida intensa y plena de vuelcos violentos de la fortuna, pues del éxito en sociedad siendo joven aún, experimentó pronto el exilio y la persecución.

Sobre su altura y belleza física, se podría decir de Alcibíades lo que Diógenes Laercio comenta sobre Jenofonte, que era exeidéstatos eis byperbolên (extremely handsome, traduce Hicks). Plutarco describe que:

Su belleza se mantuvo siempre floreciente en su infancia, su adolescencia y en la edad viril, haciéndole parecer amable y encantador en todas las etapas de su vida (...) debido a su talento y a la excelencia de su físico ${ }^{21}$.

\footnotetext{
20 Puede verse una biografía de Alcibíades en el Oxford Classical Dictionary. Oxford University Press, New York 2000.

21 Plutarco: Vidas Paralelas. Vol. III: Alcibiades y Coriolano. Gredos, Madrid 2006, I, 3; las citas siguientes corresponden a esta fuente.
} 
En tanto, Arquipo el comediógrafo lo describe como uno que: «camina con aire indolente, sensual, con objeto de ser el vivo retrato de su padre» (es decir, Cilinias). Lo cierto es que en sus actos políticos siempre pretendió ser un émulo de su tío carnal y padrastro Pericles, que hizo las veces de la figura paterna en el primer período de su educación aristocrática al interior de la clase política de Atenas. Sin embargo, Plutarco nos indica que fue por su consabida relación con Sócrates que se saben los muchos detalles de su vida, tales como, que su nodriza fue la espartana Amicla, por la que tempranamente conoció la cultura lacónica y su acento dialectal. La educación espartana era una cultura que iba por el estímulo a la competencia, en especial por la virtud militar, y por cierto que desde pequeño le gustó llamar la atención, e imponer su voluntad en los juegos con sus hermanos y amigos. Por ejemplo, se dice que fue una moda impuesta suya desprestigiar la práctica de la flauta, pues deformaba el rostro e impedía el uso normal de la voz. Le parecía más viril el arte de tocar las cuerdas del plectro y la lira, para así poder cantar o hablar mientras tocaba el instrumento ${ }^{22}$.

Por otro lado, su buena elocuencia era atendida desde temprano en las asambleas públicas y en conversaciones privadas, en donde practicaba con destreza el arte de la refutación. Se conservan algunos discursos suyos bien estructurados, y un ilustrativo diálogo refutativo con Pericles $^{23}$. No obstante su mala fama en la posteridad, Tucídides parece reconocerle talento político, en tanto que el comediante Eupolis lo describió como que «era un inmejorable conversador, pero un mediocre orador».

Su carácter exaltado y oportunista le hizo saltar por encima de aspectos importantes del protocolo religioso, moral y político de la época. Así fue como su vida amorosa fue desde joven liberal y escandalosa, pues tuvo muchos admiradores «del brillo de su belleza» y solía asistir como invitado a los symposios de la aristocracia de Atenas. En ellos Alcibíades era reconocido como bebedor excesivo, que al estilo de los macedonios, bebían el vino akratos, es decir sin mezclarlo con agua y miel como era la usanza civilizada; sin embargo, su fortaleza física le hacía resistir el beber durante días enteros ${ }^{24}$. De tal suerte, describe

\footnotetext{
22 En autores cómicos de la época se refleja la fama infausta de los sátiros y las serviles flautistas que acompañan a los amigos de Dionisio, cuyas bromas de doble sentido son abundantes. Cfr. Banquete, 176e, 212c, 215b.

23 Cfr. Jenofonte: Memorabilia, L. I, 41-47, en Memorabilia, Oeconomicus, Symposium, Apology. Trans. E. C. Marchant \& O. J. Todd, Harvard University Press/Loeb Classical Library, Cambridge 2002.

24 Banquete, 214a y ss.
} 
Plutarco que su actividad como estadista contrastaba con sus excesos en la bebida y sus amores disolutos:

Arrastraba como una mujer sus vestidos de púrpura en el ágora, haciendo alarde de una fastuosidad insultante. En los barcos no dormía en el suelo como los demás sino en una especie de litera, además se dice que bebía en copas de oro y plata que pertenecían a las liturgias del estado y lo más significativo e impresionante es que se hizo construir un escudo dorado, en donde figuraba la inusual forma de un dios Eros provisto de un rayo ${ }^{25}$.

Sus conquistas amorosas, como las del Paris troyano, no conocían límites ni fronteras, a pesar de recibir una buena dote al casarse con la noble Hipáreta, hija de Hipónico y hermana de Calias ${ }^{26}$, lo cierto es que su vida disipada era bien reconocida y al decir de Montanelli era un verdadero playboy de la época.

De sus aventuras sexuales quizás la más audaz fue durante su estadía en Esparta, donde se dice que corrompió a Timea, la esposa del rey Agis, mientras éste se hallaba en campaña militar fuera del país. Timea quedo encinta y tiempo después dio a luz a Leotíquidas. Luego Alcibíades alardeaba ante sus amigos de que no había actuado así para escarnecer al rey, ni movido por el placer, sino para que su descendencia reinara en Esparta. Sin embargo, cuando se descubrió el escándalo, los derechos dinásticos del niño fueron suspendidos, y de allí que la furia del rey espartano lo persiguió hasta el fin de sus días ${ }^{27}$. Este episodio al parecer determinó que Alcibíades huyera de Esparta y buscara refugio con el persa Tisafernes, donde llegó a ser su consejero personal. El general persa, no obstante ser seducido por su personalidad, jamás le dio ningún cargo de confianza, pero así y todo fue allí donde más contribuyó a la diplomacia de tiempos de guerra y en los más diversos bandos. La figura del camaleón, que es capaz de adaptarse a todas las situaciones, la utiliza Plutarco para describir su versatilidad, pues se dice que estando con Sócrates se avergonzaba de sus excesos ${ }^{28}$, que con los espartanos adoptó

25 Plutarco: Vidas Paralelas. Vol. III: Alcibiades y Coriolano, XVI, 2.

26 «Esta sintiéndose desgraciada en su matrimonio, porque Alcibíades frecuentaba cortesanas, tanto de la ciudad como extranjeras, abandonó su casa para ir donde su hermana», desde donde más tarde trató de ir, personalmente a divorciarse, pero Alcibíades se lo impidió violentamente, y la obligó a permanecer con él hasta que ella murió, estando aquel de viaje por Éfeso; Ibíd., VIII, 3.

27 Ibíd., XXIII, 7.

28 Cfr. Banquete, 212 y ss. en su Elogio a Sócrates. Allí Alcibíades admite que la presencia del maestro lo hacía avergonzarse de sí mismo, pero que apenas lo dejaba de frecuentar se dejaba entonces «vencer por el honor que me dispensa la multitud», Banquete, 216b. 
un estilo de vida militar y se cortó el pelo muy corto, en tanto que con los persas vestía elegantemente y era magnánimo de carácter, compitiendo en atenciones con Tisafernes. Así entonces se sabía ganar la confianza de los poderosos: mediante su carácter atlético, su pasión por los caballos, y el constante interés por la virtud que le inculcó su excelente educación y la filosofía de Sócrates, del cual adquirió las técnicas retóricas más que su amor por la justicia divina.

En tanto, de los episodios infaustos que marcaron su vida quizás el más desafortunado fue el juicio por cargo de impiedad, que se le siguió por el documentado episodio de la mutilación que sufrieron las figuras de los dioses Hermes, en la víspera del zarpe de la flota ateniense para Sicilia. Este incidente marcó el comienzo de una seguidilla de infortunios para nuestro héroe. En efecto, Alcibíades era reconocido como bebedor por sus amigos y en parte debido a esto, sumado a otras envidias políticas, sus enemigos se encargaron de inculparlo de graves cargos de impiedad. El caso es que las estatuas cuadrangulares de los Hermes se encontraban en aquella época en gran número en las entradas de las casas y en los santuarios, y fueron mutilados «en el rostro en el curso de una sola noche» ${ }^{29}$, en una acción evidente de atentado contra el dios que vela por las encrucijadas y por las empresas que comienzan. Por cierto que el clima previo, de exaltación y temor anterior a la campaña por mar, ayudó a exacerbar al máximo los ánimos del pueblo de modo que se ofreció una gran recompensa, avalada por el estado, por la delación de los culpables.

Hubo entonces unas denuncias presentadas por algunos metecos y servidores, no respecto a los Hermes profanados, sino sobre otras mutilaciones de estatuas, efectuadas anteriormente por jóvenes en un momento de juerga y borrachera. Junto a esto también denunciaron que en algunas casas se celebraban sacrílegas parodias de los misterios. Los dardos apuntaron a Alcibíades y su círculo de amigos. En tanto, Plutarco relata que el orador Androcles, enemigo mortal de Alcibíades, presentó ante el consejo algunos esclavos y metecos los cuales le acusaron a él y a sus amigos de haber parodiado los misterios de Eleusis estando todos ebrios. Dijeron que un tal Teodoro había representado el papel del heraldo, Pulitión el de portador de la antorcha y Alcibíades el de Hierofante, en tanto que el resto de sus compañeros, en calidad de mistas, asistían como espectadores. Por otro lado, la denuncia de un tal Tésalo lo acusaba de impiedad contra las dos diosas, Démeter y Perséfone.

29 Cfr. TucíDIDEs: Historia de la Guerra del Peloponeso. Obra completa, Gredos, Madrid 1990-1992, VI, 28 y ss. En lo siguiente sigo el relato de este autor. 
Los cargos eran graves y el ambiente estaba enrarecido por la indignación del pueblo, frente a lo que Alcibíades apostó con su vida para hacer un juicio rápido por el asunto de los Hermes, antes de partir con la flota junto a Nicias, -pues hubo otra versión en que los impíos habrían sido unos corintios aliados de Siracusa- pero los enemigos de Alcibíades no aceptaron la moción del juicio rápido y lograron que la flota zarpara a la mar con Alcibíades, dejando pendiente el asunto de impiedad para preparar con cuidado la causa judicial. En definitiva, este asunto hizo que Alcíbíades buscara poco después refugio en Esparta, para no comparecer al temible juicio por impiedad en Atenas.

Entretanto el perfil público de Alcibíades era el de un adepto del círculo socrático, que era una especie de secta que se caracterizaba por su afán intelectual, su interés por la virtud y una actitud permanente de crítica al sistema político vigente ${ }^{30}$. Pues a pesar de la distancia de casi veinte años entre el caso de la profanación de Hermes y el juicio por impiedad a Sócrates, la relación entre ambas causas parece evidente para sus críticos. Esta cuestión fue descrita mas tarde en una acusación (Kategoría) del sofista Polícrates como un síntoma de anarquía política, ya que ambos fueron acusados por causas de impiedad, en distintas épocas, generando análogas formas de corrupción social en cada caso ${ }^{31}$.

Por otro lado, Plutarco insiste en que:

El amor que Sócrates sentía por él puede considerarse como un gran testimonio de la disposición natural del joven para la virtud, disposición que Sócrates veía brillar y manifestarse a través de su belleza física (...) y que por eso se propuso protegerle. Pronto lo convirtió en compañero habitual, pudiendo escuchar de este modo los discursos de un amante que no perseguía vanos placeres ni requería besos y caricias, sino que le descubría las imperfecciones de su alma, y le reprimía su necio y vano orgullo de suerte que: se agachó como un gallo derrotado, con el ala caída.

30 Esta era al menos la opinión del comediógrafo Aristófanes en su célebre comedia Nubes. Por otro lado, Plutarco señala una anécdota ilustrativa relata que una vez el joven Alcibíades quiso ver a su tío-mentor Pericles para hablarle, pero los sirvientes le dijeron que no lo podía recibir, pues estaba ocupado en preparar una cuenta pública a los atenienses, a lo que comentó, «que sería mejor que buscara el medio de no tener que rendir cuentas». Estas actitudes críticas y de desdén al sistema se verán también reflejadas en ideas racionalistas en temas de religión, que despreciaban la superstición y el ritualismo como algo poco útil.

31 La Kategoría es un género literario de la época sofística que tiene la forma de acusación. Este texto perdido es aludido en el libro I, 2, 9 de Memorabilia de Jenofonte, como soporte para refutar en la primera de sus apologías. Al final del libro hay otra versión del tema. Por otro lado, los epítetos superlativos con que Jenofonte describe a Alcibíades en Mem. I 2, 16 son akratóstatos, bybrístatos kai biaiótatos, el más disoluto, el más irrespetuoso y el más violento. 
La obra de Sócrates era realmente un ministerio que los dioses le habían encomendado para el cuidado y la salvación de la juventud. Y así fue Alcibíades despreciándose a sí mismo y admirando a Sócrates, de quien amaba su bondad y respetaba por su virtud. De tal modo, todos se admiraban de verle comer con Sócrates, y luchar y compartir con él su tienda de campaña, mientras que con el resto de sus amantes se mostraba áspero y desabrido puesto que «Sócrates era el único por el que sentía respeto y temor; y los demás amantes sólo le inspiraban desprecio» ${ }^{32}$.

\section{Hacia el personaje Alcibíades platónico}

Esta relación con Sócrates contribuyó enormemente a su celebridad postrera y es aquí donde vemos que Platón también confirma su estrecha relación. En efecto, más allá de la famosa escena final del Banquete, el autor Platón, en su Alcibiades I, narra lo que se supone fue su primer y decisivo encuentro. De tal manera, en el prólogo dramático de este diálogo, Sócrates declara haber sido el primero en enamorarse de él y que además su amor por el joven Alcibíades ha sido constante en comparación con sus otros enamorados. Al mismo tiempo le confiesa que durante años ha querido acercársele, pero que una señal divina se lo había impedido hasta ese momento ${ }^{33}$.

De allí en más esta breve pieza maestra de Platón discurrirá sobre la virtud de la justicia, primero mediante su método inductivo habitual de preguntas y respuestas cortas, y luego girando en torno al punto central de la educación para la política, lo que hace que esta pequeña obra resulte como una especie de reseña de la República. En tanto, y a diferencia de los diálogos tempranos de Platón, en la segunda parte y final de la obra, la pedagogía socrática se muestra cada vez menos inductiva y por lo tanto más doctrinal, donde se muestra la clara intención que tiene de mejorar al amado, ya sea mediante la directa interpelación a la virtud, con la aplicación del método de refutación de las opiniones infundadas, o induciéndolo a la toma de conciencia de sí mismo, mediante ingeniosos símiles que representan el alma interior. Tal es el caso de las imágenes que se miran reflejadas en las pupilas de los ojos, y que conducirán a prestar una mayor atención al cuidado de sí mismo. Este símil de ejercicio a fin de cuentas se convertirá en experiencia de

\footnotetext{
32 Plutarco: Vidas, Paralelas. Vol. III: Alcibiades y Coriolano, VI, 1.
}

33 Sócrates tiene de todo tipo de discípulos entre los que son permitidos por su daimon personal. Por ejemplo, Arístides era uno de aquellos que: «progresan admirablemente mientras están a mi lado, pero cuando se alejan, de nuevo dejan de diferenciarse de cualquier otro», Teages, 130ab. Cfr. Teeteto, 151a; Banquete, 212a. 
autoconocimiento y del auto cuidado (epimeleia eis autô), en una vivencia que se cumplirá a cabalidad en la relación especulativa de un alma con otra alma, tanto en la amistad filosófica entre pares, como en la relación dialéctica del maestro y el discípulo.

Afirmamos, entonces, que en este escenario de intimidad espiritual el irónico eros socrático se expresará como una relación «de padre a hijo o de hermano mayor a menor», y en particular a través de la forma concomitante del maestro y el discípulo ${ }^{34}$. Esta dinámica personal también se sostiene y comprende en la forma del amante y del amado, relación propia de las amistades griegas y que se ponía a prueba en el duro escenario de las campañas militares ${ }^{35}$.

En tanto, nuestro Sócrates, que afirma tener una docta ignorancia en general, parece saber algo sobre temas de amores (ta erotik $\hat{a}$ ) y por tanto puede dar algunas lecciones sobre eros y filia, pues llega a confesar que: «no sé nada excepto un insignificante conocimiento sobre el amon» ${ }^{36}$.

Como ejemplo de esto, y para efectos de hacer amigos en gimnasios y lugares públicos, Sócrates es un consabido maestro en el arte de seducir a los jóvenes mediante simulaciones, como una acción propia de un irónico (eirón) o mediante estudiados trucos retóricos ${ }^{37}$.

Dicho lo anterior, a continuación revisaremos un texto bastante menos reconocido como uno auténticamente platónico, pero que es muy pertinente para el presente propósito de aclarar la forma de la piedad filosófica, pues a pesar de ser considerado dudoso, exhibe las ideas

34 En la Apología de Sócrates, 31b y en Banquete, 219d, se caracteriza el eros socrático con la figura de una relación semejante a un padre o un hermano mayor. Sobre este punto véase mi Nota: "El eros socrático: perfil de una figura de la literatura filosófica", Diadokhe, vol. 2 (1999), 133-139.

35 La relación de amante-amado como una relación análoga a la del discípulomaestro, es mencionada de modo sarcástico por Sócrates hacia el adivino en Eutifrón (cfr. 14c). Por otro lado, está documentado que Sócrates no sólo le salvó la vida a Alcibíades, sino que además renunció a honores en favor de su amigo (cfr. Banquete, 220e). Además, según el cronista Estobeo, también salvó la vida de Jenofonte en circunstancias parecidas, pues considerando que ambos jóvenes atenienses eran aristócratas y que formaban parte de la caballería, posiblemente sufrieron caídas violentas en la batalla desde sus cabalgaduras, hasta que el hoplita Sócrates los salvó, cargándoles en andas en cada caso.

36 Teages $128 \mathrm{~b}$.

37 Sócrates es reconocido como un gran seductor de jóvenes. Por ejemplo en Lisis (206a), explica a sus amigos su método de seducción irónica, que utiliza para conseguir amigos jugando a ser indiferente; o en Cármides (156d), donde inventa una excusa médica para acercarse al joven; o en Menéxeno (236d), en donde se declara abiertamente su admirador. Lo común de todos estos modos de aproximación es que sirven para llegar a entablar una conversación con alguno de sus favoritos. 
fuerza que hemos estado de siguiendo sobre la recta piedad y su relación con la justicia en la filosofía de Sócrates.

\section{Alcibíades II, sobre la plegaria (peri eujés)}

En esta oportunidad Sócrates se encuentra por casualidad con Alcibíades, que va de camino para realizar una ofrenda a un dios no denominado. La ocasión dará lugar a un interesante diálogo entre maestro y discípulo en torno a la actividad religiosa. Sócrates comenzará utilizando el habitual método analógico de comparación entre la virtud y el arte experto, pero esta vez enfocado sobre el modo correcto de dirigirse a los dioses mediante las actitudes y las plegarias correctas ${ }^{38}$.

Así, entonces, en esta pequeña obra — de cierta semejanza con el diálogo temprano Eutifrón - se tratará de definir una acción que precisa del saber hacer y decir lo que es más apropiado en la relación con lo divino, y esta excelencia o virtud, se describe aquí como la propia del hombre sensato (sofron). La sensatez, se dirá en tanto, es lo contrario de la insensatez. Esta forma de ignorancia puede tener diversos grados de deficiencia, que van desde la locura a la exaltación, pasando por diversas formas de necedad. Esta última cuestión es ajena al hombre que sabe lo que es bueno, vale decir, el que reconoce lo que es útil en cada caso. Sobre esta línea de razonamiento está claro que el hombre sensato es también el prudente y justo, tanto en su relación con los hombres, como también en su comprensión de lo relativo a los dioses. Por el contrario, el que es ignorante de estas cosas -el insensato, el necio o el exaltadono atinará con el modo correcto de la actividad humana que llamamos vida piadosa, esto es, hacer y decir lo que es conveniente en relación con los dioses. Pues resultará que el insensato puede llegar a pedir a los dioses algo que se le antoja como un bien, pero que finalmente puede resultar un gran mal para el hombre imprudente.

¿Cómo librarse entonces de la vana ambición, y en caso extremo de la soberbia en las peticiones a los dioses (bybris)? Un ensalmo eficaz resulta ser la plegaria correcta, propia de un hombre sensato, y que Sócrates atribuye a un poeta desconocido, y que reza así:

Zeus soberano, danos los bienes, tanto si te los pedimos como si no. Pero los males, aunque te los pidamos, apártalos de nosotros ${ }^{39}$.

38 Eutifrón también define a la piedad como la parte de la justicia relativa a la relación entre los hombres y los dioses, que sería una especie de cuidado (therapeia) de los dioses. La parte restante de la justicia es la que se refiere a los hombres. Cfr. Eutifrón, $12 \mathrm{e}$.

39 Cfr. JenOfonte: Memorabilia, 1.3.2. 
Esta fórmula enigmática parece ser la oración más perfecta del racionalismo teológico en el Sócrates platónico que, en lo fundamental, consiste en la intuición de fondo acerca de la naturaleza de los dioses; es decir, de que estos son totalmente buenos y por tanto son fuente de toda forma de bondad, donadores de los verdaderos bienes y nunca de los males, ya que esto escaparía de su naturaleza perfecta y divina. Ya que aún cuando el insensato puede desear y pedir algún favor personal a los divinos númenes, si a éste orante no le acompaña el discernimiento moral - vale decir, la virtud del saber distinguir el bien del mal- lo que parece ser un bien útil, puede finalmente revelarse como un mal destructivo. El caso presente, de la intención de Alcibíades, hijo de Clinias e hijastro de Pericles, no está expuesto aquí con detalle, pero su perfil biográfico indica que siempre aspiró a llegar a ser un estratega o un gran tirano de Atenas. Lo cierto es que la ambición por la obtención de poder derivó en una larga serie de calamidades y, en definitiva, en la causa del encargo de su muerte violenta.

Pero volvamos, al texto de Alcibiades II, donde otro ejemplo elocuente, que refuerza la noción de una justa y sensata piedad, es la de la plegaria que practicaban los Lacedemonios. Según esta tradición se les pide a los dioses junto con los dones divinos, tener una buena conciencia moral. Esta virtud cívica exigida por los dioses era, según el relato de Sócrates, mucho mejor valorada que las famosas hecatombes perfectas de los atenienses o los troyanos. Pues si bien la piedad tradicional de mentalidad mítica, se puede describir como una especie de comercio entre los dioses y los hombres ${ }^{40}$, lo cierto es que el beneficio de esta transacción será siempre unilateral, dada la desproporción que existe entre la humanidad imperfecta y la divina perfección de oi theoi. Así las cosas lo que resulta, en esta dinámica de traspasos asimétricos, es una donación unilateral de los bienes divinos por el lado alto y, por otro, la recepción agradecida y también unívoca de los fieles mortales.

El punto de inflexión entonces parece que ya está bien demarcado en la pre-comprensión de la piedad socrática que, desde su base, está concebida como una justa relación entre las partes, y que propongo provisionalmente formalizar con las siguientes premisas mayores:

$\left.1^{\circ}\right)$ Los dioses son únicamente fuente de toda bondad.

$\left.2^{\circ}\right)$ Los hombres resultan ser los puros receptores de estos dones.

$\left.3^{\circ}\right)$ Se puede concluir entonces que no hay relación de reciprocidad con los dioses en la piedad verdadera.

40 Cfr. Eutifron, 15a. 
Teniendo presente los rendimientos racionalistas que se exhiben desde el Eutifron platónico, esto finalmente implicaría las siguientes conclusiones:

-Los dioses serían indiferentes a las ofrendas que buscan persuadirlos, pues no pueden variar su acción de donación por el interés humano;

-Luego, el modo correcto de ser justos con lo que ellos representan para el piadoso sería mediante la práctica de la recta piedad, que consiste en el mejoramiento del alma por la práctica de la justicia, transformándose, en definitiva, la piedad socrática en práctica ética.

-Como rendimiento inmediato y consecuentemente con lo anterior, la práctica de la religiosidad popular, que consiste en presentar ofrendas materiales y sacrificios a los dioses, no sería un dispositivo que surta los efectos deseados de persuadir a los seres perfectos para que se ocupen de lo imperfecto. Por lo tanto, el sentido de la piedad, como un intercambio de bienes, no tendría razón de ser, sobre todo en el caso de que la piedad fuera caracterizada como una especie de arte comercial (techné ta emporikâ).

La situación anterior deja aparentemente disminuida la utilidad de ciertas prácticas tradicionales de acercamiento a lo divino, sin embargo, la parte que subsiste de la piedad -en su versión que suponemos socrática- consistirá en que la relación con lo divino tiene un vuelco unilateral hacia la práctica de la virtud. Este renovado sentido unívoco consiste en que los seres humanos -ilustrados por el racionalismo teológico de Sócrates- aspiran a emular a los seres perfectos, dioses justos y buenos, mediante un progresivo proceso de divinización o de asimilación a lo perfecto, y que el hombre sensato cumpliría con la búsqueda permanente y práctica de la justicia, que es divina en su origen. En consecuencia, el plano de acción piadosa girará entonces en torno a la ética más que a la esfera ritual de la religión tradicional.

Es aquí donde la religión de Sócrates toma distancia definitiva de la tradición mítica y se transforma en una ética de virtudes, pero con un fuerte ingrediente místico. Más adelante, en la obra de Platón se observará un giro religioso con referencias más explícitas a movimientos religiosos que provienen del estilo órfico y pitagórico, y que vienen a salvar - al menos desde el mito escatológico del Gorgias y del Fedón en adelante- ese aparente vacío de representaciones en el plano de la experiencia religiosa, como un vínculo discursivo necesario para tender 
puentes verosímiles entre las creencias populares y el saber práctico ilustrado, propiamente exhibido por el Sócrates platónico medio en sus singulares acciones virtuosas y sus actos de habla ${ }^{41}$.

No obstante, ya está señalado que en el SPT la religión se interiorizó y se convirtió fundamentalmente en acción ética y, como efecto inmediato de ello, se clausuró el sentido de la dimensión sacrificial de la piedad a un plano puramente humano e inmanente. Esto equivale a decir que la efectividad de la devoción no alcanzaría a los dioses pero que, sin embargo, podría subsistir un cierto conato de sentido. Primero, en la dimensión social y política, donde la piedad cívica cumple importantes funciones unificadoras de la esfera social, que desde sus márgenes temporales, acude al centro de la fiesta religiosa para cumplir en las efemérides los rituales del encuentro para la construcción de las identidades sociales e históricas.

En todo caso, y volviendo al racionalismo socrático radical que delineamos más arriba, esta dinámica de una piedad orientada a la perfección moral, se comprenderá mejor sumando la figura central de la relación entre el maestro y el discípulo, en donde aquél funge como un modelo para éste y en donde si bien se asemeja en parte a la relación asimétrica del hombre piadoso con lo divino, la diferencia radical estriba en que, en este símil del magisterio, subsiste una relación asimétrica de reciprocidad - que es como la del amante y del amado en el esquema platónico del Banquete- donde se cumple un intercambio desigual, como de oro por bronce, de eros por filia, y en definitiva de amor por amistad. Por otra parte, en la relación del sabio con el dios socrático, lo divino también le provee de un nivel orientador para el hacer del hombre sensato, pero a fin de cuentas, en una relación definitivamente unilateral hacia la dimensión de lo paradigmático.

Entonces, y en relación al proceso de Sócrates, acusado de impiedad por una facción conservadora de la polis en materia de religión, tenemos buenos argumentos para comprender la responsabilidad moral que le cabe a Sócrates en su magisterio de nuevas formas de comprensión de lo divino; es decir, de su filosofía racionalista y teocrítica, que se describe también como una actividad dialogante e inquisitiva que introduce nuevas formas de comprensión de la naturaleza de la divinidad, y que de paso rechaza como impropias a las creencias tradicionales -léase míticas,

41 En la Apología de Sócrates encontramos al menos una decena de paradojas que se siguen de esta actitud mística y racionalista, pero a partir del período medio de Platón su actitud se torna más propositiva y menos rupturista con las formas de representación de lo divino. 
supersticiosas, mágicas, de tipo comercial y transaccional- que se sostenían con las esferas divinas de la realidad.

El peligro inminente es entonces que si la verdadera piedad acentúa en demasía la dimensión ética, del hacer y el decir, se corre el riesgo de dejar vacío de contenido el gesto ritual de la gente sencilla, no ilustrada, y cuyo sentimiento de vinculación con los poderes supremos, arraigado en la religiosidad popular, tiende puentes de piedad a través de los votos, las ofrendas y las mandas, todas formas de carácter transaccional, en circunstancias de que el dios perfecto guarda silencio en su esfera de perfección, mientras que el pobre piadoso seguirá quemando víctimas o inciensos para cumplir el ritual del encuentro con el poder divino. Por su parte, para este SPT la más legítima piedad se realiza en el drama silencioso de la buena voluntad, en la esfera interna, en donde se resiste al mal con disposiciones virtuosas y donde se decide de forma libre la opción por la justicia con la ayuda de señales de origen divino.

A partir de este escenario espiritual que hemos denominado racionalismo teológico, la práctica de la oración sufriría también un gran giro en la orientación de su sentido existencial, pues si los dioses callan frente a los manifiestos deseos del hombre, el piadoso pareciera quedarse a solas con su oración. Sin embargo, el piadoso se descubre a sí mismo en este íntimo acto del habla del corazón, que no es más que el espejo de su propia voluntad de ser, siendo su relato reflexivo como un reflejo del sí mismo que le enrostra el propósito más profundo del alma. Así como la mirada del otro puede ser el mejor modo de caer en cuenta de la propia naturaleza, en la plegaria también puede que ocurra algo análogo, pues esta objetivación frente a lo perfecto reflejará una profunda experiencia de sí mismo, que surge del afán de alineamiento con la fuente metafísica del bien y de la justicia.

Por último, la plegaria silenciosa del que contempla el bien y la unidad, junto con ser síntesis solitaria de la vida interior, es también la instancia en que el alma del hombre se muestra inquieta en su proceso de divinización hasta que descanse en la paz del misterio.

\section{Coda final a modo de conclusiones}

La estrecha relación de Sócrates con Alcibíades es un hecho claramente demostrado, y la paradoja mayor de este discipulado parece ser que la naturaleza del siempre jovial Alcibíades nunca pudo ser permeable a las enseñanzas de su maestro ni alcanzar a madurar el proyecto educativo del socratismo que, aportándole de todos los elementos espirituales que estuvieron a su alcance - entre los que 
destacamos sus opiniones racionalistas en materia de religión- no logró convertir a esta personalidad brillante hacia la forma esotérica singular de la piedad ética que representa al hombre justo del socratismo. De tal suerte, y al estilo de los grandes héroes trágicos, Alcibíades sucumbirá gradual, pero inexorablemente, bajo la influencia de un racionalismo mal entendido y perverso en sus aspiraciones, marcadas a fuego por su incansable deseo (léase eros) por alcanzar la virtud de la vida pública y que, no obstante tener todas las cualidades necesarias de espíritu y de clase, resultó finalmente en fatalidad ya que, como al hijo de Dédalo, su ambición desmedida lo condujo a una caída fatal, desde su pasión política hacia la muerte infame, tal como un gran héroe trágico que no pudo salvarse de su propio destino inevitable.

Sumario: Prolegómenos; I. La pasión por la justicia en el SPT; 1. Las tesis positivas del Eutifrón de Platón; 2. La piedad socrática se convierte en ética; 3. Una alegoría paralela desde el estoicismo; II. La pasión por Alcibíades; 1. Algunos aspectos psicohistóricos; 2. Hacia el personaje Alcibíades platónico; 3. Alcibiades II, sobre la plegaria (peri eujés); Coda final a modo de conclusiones. 